\title{
Grain-Size Distribution and Chemical Speciation of Heavy Metals in Chinese Street Dust
}

\author{
Fengman Fang1,2*, Yangbing $\mathrm{Li}^{2}$, Yuesheng Lin ${ }^{1}$, Minglu $\mathrm{Xu}^{1}$ \\ ${ }^{1}$ College of Territorial Resources and Tourism, Anhui Normal University, Wuhu 241003, China \\ ${ }^{2}$ College of Life Sciences, Anhui Normal University, Wuhu 241000, China
}

Received:18 November 2016

Accepted: 8 February 2017

\begin{abstract}
In order to assess the grain-size distribution and chemical speciation of heavy metals, 34 dust samples were collected in the city of Wuhu. Heavy metals concentrations in street dust of different districts varied greatly. $\mathrm{Zn}$ concentration in the traffic district, for example, is more than two times that of other districts, and $\mathrm{Cu}$ concentration in the industrial district is more than three times that of other districts. Zn mainly comes from traffic sources, and $\mathrm{Cu}$ mainly comes from industrial emissions sources. The highest concentrations of $\mathrm{Cu}$ and $\mathrm{Cd}$ appeared in the particle size of $<75 \mu \mathrm{m}$, and the other heavy metals appeared in the particle size of 96-75 $\mu \mathrm{m}$. Heavy metals concentrations for different speciation appeared in an increasing trend with a reduction in particle size. $\mathrm{Zn}$ and $\mathrm{Cd}$ were mainly bound to acid-extractable state. $\mathrm{Cr}, \mathrm{V}, \mathrm{Ni}$, and Co elements were mainly bound to a residual state. $\mathrm{Cu}$ and $\mathrm{Pb}$ were mainly bound to an organic state. The grain size fraction loads $\left(\mathrm{GSF}_{\text {Load }}\right)$ of different chemical speciation were mainly high in fine particles. The biological mobility of heavy metals in street dust decreased in the order of $\mathrm{Pb}(91 \%)>\mathrm{Cu}(85.6 \%)>\mathrm{Zn}(85.24 \%)$ $>\operatorname{Cd}(78.3 \%)>\operatorname{Co}(49.3 \%)>\operatorname{Ni}(39.3 \%)>V(23.7 \%)>\operatorname{Cr}(20.19 \%)$. Bioavailability of Cu emitted from industrial sources was high.
\end{abstract}

Keywords: surface dust, heavy metals, chemical speciation, grain-size distribution, Wuhu

\section{Introduction}

Over the last several decades, heavy metals content in urban street dust has received increasing attention because of the associated health hazards and risks [1-3]. The spatial distribution, accumulation, and environmental effects of heavy metals in dust have been researched [4-9].

The particle size fractions of dust will influence the mobility of heavy metals. The amount of dust inhaled and ingested by humans is usually dependent on grain size. Studies of the particle size fractions of street dust have

*e-mail: ffm1974@mail.ahnu.edu.cn been conducted since the 1980s [7, 10-14]. Deletic and Orr [12] reported that the max concentrations of heavy metals in Arab street dust appeared in the particle size of 2-63 $\mu \mathrm{m}$. McKenzie et al. [15] reported that $\mathrm{Cr}, \mathrm{Ni}, \mathrm{Cu}$, $\mathrm{Zn}$, and $\mathrm{Pb}$ were mainly enriched in the fine particle dust of $<1.5 \mu \mathrm{m}$. But $\mathrm{Co}$ and $\mathrm{Vi}$, which come from natural sources, were mainly enriched in coarse sizes of 5001,000 $\mu \mathrm{m}$ [5-6].

The chemical speciation of heavy metals in street dust decided their activity and bioavailability in the environment. Most metals existed in the speciation of non-residual state, such as organic-sulfide combining and Fe-Mn oxide state [12, 16-17]. Studies mainly focused on the chemical speciation research of heavy 
metals in street dust, while little information is available on heavy metals concentration and geometrical shape of the proportion in the different particles. Chang et al. [18] studied particle effect and bioavailability of heavy metals in street dust of Shanghai, and their results showed that the grain-size distribution had little influence on exchange state concentrations of $\mathrm{Zn}, \mathrm{Pb}, \mathrm{Cd}, \mathrm{Ni}, \mathrm{Cu}$, and $\mathrm{Cr}$. But the carbonate, Fe-Mn oxide combination, and organic combination concentrations of $\mathrm{Cd}$ and $\mathrm{Pb}$ were significantly influenced by particle size distribution.

Fang et al. [19] reported that high concentrations of heavy metals appeared on street dust in the city of Wuhu. The main objectives of this study are: 1) to determine the concentrations of acid-extractable, reducible, oxidizable, and residual state of heavy metals in street dust with the BCR sequential extraction procedure by the European Community Bureau of Reference and 2) to discuss grain size distribution and biological activity of heavy metals in Wuhu street dust. The above objectives are useful for both helping the government establish protective measures and to alleviate heavy metals pollution of non-point control.

\section{Materials and Methods}

\section{Study Area}

Wuhu $\left(118^{\circ} 46^{\prime} \mathrm{E}, 31^{\circ} 20^{\prime} \mathrm{N}\right)$ is the subcenter city of Anhui province in the southeast of China, located in the south of the Yangtze River. In order to better study the relationship between human activity and heavy metal distribution characteristic in street dust, the study region was divided into industrial district, business district, traffic district and residential district according to industry layout, traffic flow, human activities and other characteristics in Wuhu city.

\section{Samples Acquisition and Processing}

Details of the study area and sampling method can be seen in Fang et al. [19]. Dust samples were collected using a brush and white plastic collection pan. Each brush and pan was used only once or cleaned using acetone. At each sampling site, four sub-samples were collected randomly and then mixed thoroughly to obtain a bulk sample.
Thirty-four street dust samples were collected from four functional districts in Wuhu, including 10 in an industrial district, eight in a residential district, seven in a business district, and nine in a traffic district. Samples were air-dried naturally in the laboratory, debris and small stones were removed using stainless steel tweezers, and then the samples were sieved through $830 \mu \mathrm{m}$ nylon mesh. Half was used for particle size analysis. Another part of the $250 \mu \mathrm{m}$ samples was ground with an agate mortar, then carefully homogenized and sieved through $150 \mu \mathrm{m}$ nylon mesh. The milled samples were used for heavy metals concentration determination by BCR extract steps. Eleven samples were chosen (including traffic district 2, business district 3, residential district 3 , industrial district 3) and sieved through $830 \mu \mathrm{m}$, $250 \mu \mathrm{m}, 150 \mu \mathrm{m}, 96 \mu \mathrm{m}$, and $75 \mu \mathrm{m}$ nylon mesh, respectively, then the samples were divided into five particle-size levels, including 830-250 $\mu \mathrm{m}, 250-150 \mu \mathrm{m}$, 150-96 $\mu \mathrm{m}, 96-75 \mu \mathrm{m}$, and $<75 \mu \mathrm{m}$. 830-250 $\mu \mathrm{m}$ and 250-150 $\mu \mathrm{m}$ samples were sieved through $150 \mu \mathrm{m}$ nylon mesh with an agate mortar.

\section{Experimental Analysis}

In order to measure the total amount of heavy metals, about $0.2 \mathrm{~g}$ of the prepared dust sample was digested with a concentrated $\mathrm{HNO}_{3}-\mathrm{HClO}_{4}$ - $\mathrm{HF}$ mixture and diluted with $2 \% \mathrm{HNO}_{3}$ to $50 \mathrm{~mL}$. Sequential extraction was performed using a three-stage modified procedure recommended by BCR, which has been used for several studies [20]. The elements chemical speciation were divided into four types: acid-extractable state, reducible state, oxidizable state, and residual state (Table 1). Subsequently, the concentrations of $\mathrm{Zn}, \mathrm{Pb}, \mathrm{Cr}, \mathrm{Cu}, \mathrm{Ni}, \mathrm{Cd}, \mathrm{V}$, and Co were determined by using an inductively coupled plasma-optical emission spectrometer (ICP-OES).

\section{Quality Control}

All the containers used during sample analysis were washed with detergent, acid-soaked (10\% nitric acid), and then rinsed thoroughly with deionized water. GBW07401 (GSS-1) and GBW07403 (GSS-3) certified reference materials were used to analyze the precise and accurate measurements. The average recoveries of heavy metals in the GSS materials were between 90.6 and $114.1 \%$. Reagent

Table 1. Extracting and analyzing flow of the modified BCR.

\begin{tabular}{|c|c|c|c|c|}
\hline Step & Extractant & Sample: solution $/ \mathrm{g} \mathrm{mL}^{-1}$ & Extraction Time & Speciation \\
\hline 1 & $0.11 \mathrm{~mol} / \mathrm{L} \mathrm{CH}_{3} \mathrm{COOH} \mathrm{HOAc}$ & $1: 40$ & Oscillate $16 \mathrm{~h}$ & Acid-extractable \\
\hline 2 & $0.1 \mathrm{~mol} / \mathrm{L} \mathrm{NH}_{2} \mathrm{OH} \cdot \mathrm{HCL}$ & $1: 40$ & Oscillate $16 \mathrm{~h}$ & Reducible \\
\hline \multirow{2}{*}{3} & $8.8 \mathrm{~mol} / \mathrm{L} \mathrm{H}_{2} \mathrm{O}_{2}, \mathrm{pH} 2-3,85^{\circ} \mathrm{C}$ & $1: 10$ & $1 \mathrm{~h}$, Occasionally oscillate & \multirow{2}{*}{ Oxidizable } \\
\cline { 2 - 4 } & $8.8 \mathrm{~mol} / \mathrm{L} \mathrm{H}_{2} \mathrm{O}_{2}, \mathrm{pH} 2-3,85^{\circ} \mathrm{C}$ & $1: 10$ & $1 \mathrm{~h}$, Occasionally oscillate & \\
\cline { 2 - 4 } & $1 \mathrm{~mol} / \mathrm{L} \mathrm{NH}_{4} \mathrm{OAc}, \mathrm{pH}=2$ & $1: 50$ & Oscillate $16 \mathrm{~h}$ & \multirow{2}{*}{ Residual } \\
\hline
\end{tabular}


blanks and analytical duplicate samples were included to ensure the accuracy and precision of analysis. All chemicals used for metals measurement were guaranteed reagents.

\section{Results and Discussion}

\section{Heavy Metals Concentrations in Street Dust}

The mean concentrations of heavy metals for 34 street dust samples of $\mathrm{Zn}(365.25 \mathrm{mg} / \mathrm{kg}), \mathrm{Cd}(2.23 \mathrm{mg} / \mathrm{kg})$, $\mathrm{Pb}(82.3 \mathrm{mg} / \mathrm{kg}), \mathrm{Co}(9.00 \mathrm{mg} / \mathrm{kg}), \mathrm{Ni}(22.82 \mathrm{mg} / \mathrm{kg}), \mathrm{Cr}$ $(55.19 \mathrm{mg} / \mathrm{kg}), \mathrm{V}(59.92 \mathrm{mg} / \mathrm{kg})$, and $\mathrm{Cu}(196.83 \mathrm{mg} / \mathrm{kg})$ of Wuhu were low compared with some large and mediumsized cities in China. $\mathrm{Zn}, \mathrm{Pb}$, and $\mathrm{Cr}$ concentrations affected by traffic activity were lower than those in Shanghai, Beijing, and Baoji $[18,21]$. The reason is because the city scale, population density, and traffic flow of Beijing and Shanghai far exceed those of Wuhu. Baoji is a heavy industry city and transportation hub. Heavy metals from traffic and industrial emissions were discharged into an urban environment with particulate matter. $\mathrm{Cu}$ concentration in urban street dust in Wuhu was close to the level in Shanghai, and far higher than the level in Baoji and Beijing [18, 21-22], which can be explained by the fact that the automobile industry is the leading industry of Wuhu. Cd concentration in Wuhu dust was obviously higher than the level in Shanghai, caused by the high soil background value of $\mathrm{Cd}$ in Wuhu. Therefore, population scale, traffic flow, leading industry, and background value can affect the heavy metals concentrations in urban dust.

\section{Heavy Metals Concentrations in Street Dust from Different Functional Districts}

Heavy metal concentrations in street dust from different functional districts in Wuhu are presented in Fig. 1. Zn concentration decreased in the order of traffic district $(614.54 \mathrm{mg} / \mathrm{kg})>$ industrial district

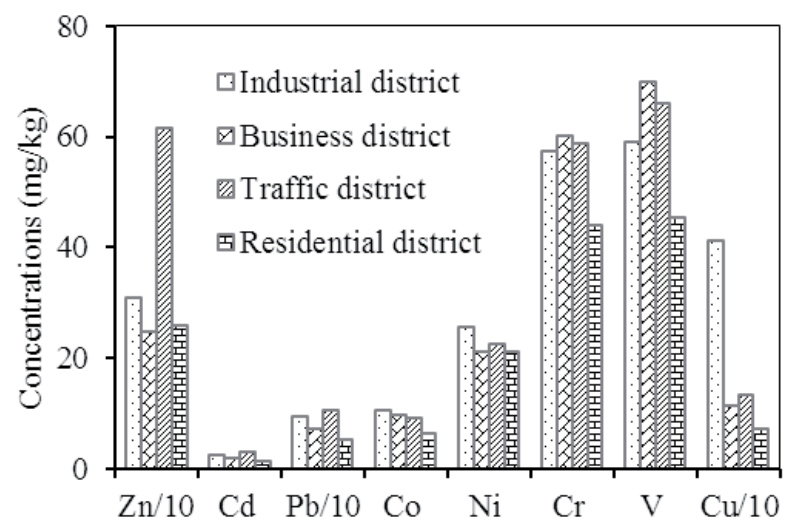

Fig. 1. Concentrations of heavy metals in street dust in different functional districts of Wuhu city.
$(307.87 \mathrm{mg} / \mathrm{kg})>$ residential district $(260.21 \mathrm{mg} / \mathrm{kg})>$ business district $(246.72 \mathrm{mg} / \mathrm{kg})$. Zn concentration in the traffic district was more than two times the concentration in other functional districts. The results showed that $\mathrm{Zn}$ concentration is mainly affected by traffic activities. $\mathrm{Cd}$ and $\mathrm{Pb}$ concentrations decreased in the order of traffic district $>$ industrial district $>$ business district $>$ residential district. $\mathrm{Pb}$ and $\mathrm{Cd}$ concentrations in the traffic district are two times more than those in the residential district. $\mathrm{Pb}$ and $\mathrm{Cd}$ were also affected by fuel burning release, in addition to traffic emissions. The $\mathrm{Cu}$ concentration decreased in the order of industrial district $(413.24 \mathrm{mg} / \mathrm{kg})>$ traffic district $(134.14 \mathrm{mg} / \mathrm{kg})$ $>$ business district $(112.46 \mathrm{mg} / \mathrm{kg})>$ residential district $(70.67 \mathrm{mg} / \mathrm{kg}) . \mathrm{Cu}$ concentration in the industrial district was three times more than those in other districts due to $\mathrm{Cu}$ released by the process of auto industry production, and meanwhile $\mathrm{Cu}$ concentration in industrial district soil was high [23]. Concentrations of $\mathrm{Co}, \mathrm{Ni}, \mathrm{Cr}$, and $\mathrm{V}$ were not significantly different in different functional districts. $\mathrm{Cr}$ and $\mathrm{V}$ concentrations decreased in the order of business district $>$ industrial district $>$ traffic district $>$ residential district. In addition to $\mathrm{Zn}$, the lowest concentrations of $\mathrm{Cd}, \mathrm{Pb}, \mathrm{Cu}, \mathrm{V}, \mathrm{Ni}$, and $\mathrm{Co}$ appeared in the residential district, therefore heavy metals concentrations in street dust of the residential district was less affected by human activities. The spatial difference of heavy metals (such as $\mathrm{Zn}$ and $\mathrm{Pb}$ ) affected by traffic source was not significantly different from that of $\mathrm{Cu}$ affected by industrial pollution, which is explained by the clear boundary of the centered industrial distribution. With the development of traffic, traffic emissions affect all areas of the city. On the whole, $\mathrm{Zn}, \mathrm{Pb}, \mathrm{Cu}, \mathrm{V}$, and $\mathrm{Cr}$ concentrations varied greatly in different functional districts, and $\mathrm{Ni}, \mathrm{Cd}$, and Co concentrations have no obvious difference in different functional districts.

\section{Heavy Metal Loadings in Different Particle Size Fractions in Street Dust}

The results of grain-size distribution of heavy metals are presented in Table 2. The highest concentrations of $\mathrm{Cu}$ and $\mathrm{Cd}$ appeared in the particle size of $<75 \mu \mathrm{m}$, and the highest concentrations of other heavy metals appeared in the particle size of 96-75 $\mu \mathrm{m}$ (Table 2). Variance analysis showed that $\mathrm{Co}, \mathrm{Zn}$, and $\mathrm{V}$ concentrations in each particle size have no obvious difference in the $5 \%$ confidence level. $\mathrm{Cd}$ and $\mathrm{Cu}$ concentrations in particle sizes of 150-96 $\mu \mathrm{m}, 96-75 \mu \mathrm{m}$, and $<75 \mu \mathrm{m}$ were higher than the levels in particle sizes of $>150 \mu \mathrm{m}$. $\mathrm{Cr}, \mathrm{Pb}$, and $\mathrm{Co}$ concentrations in particle sizes of $830-250 \mu \mathrm{m}$ were obvious difference compared with the other particles. Ni concentration in the particle size of $96-75 \mu \mathrm{m}$ was obviously higher than that in other particle sizes. Overall, the results of grain-size distribution of heavy metals indicated that metals tend to be associated with fine particles. Han et al. [5] reported that heavy metals in the dusts of Baotou were largely accumulated in the particles of $<50 \mu \mathrm{m}$. Chang et al. [18] reported that heavy metals in street dust of 
Table 2. Concentrations of heavy metals in different particle sizes of street dust (mg/kg).

\begin{tabular}{|c|c|c|c|c|c|c|c|c|}
\hline Particle size & $\mathrm{Zn}$ & $\mathrm{Cd}$ & $\mathrm{Pb}$ & $\mathrm{Co}$ & $\mathrm{Ni}$ & $\mathrm{Cr}$ & $\mathrm{V}$ & $\mathrm{Cu}$ \\
\hline $830-250 \mu \mathrm{m}$ & 177.03 & 2.71 & 66.82 & 10.00 & 12.82 & 26.29 & 38.28 & 119.67 \\
\hline $250-150 \mu \mathrm{m}$ & 179.87 & 2.96 & 77.52 & 11.04 & 19.34 & 32.26 & 51.35 & 142.75 \\
\hline $150-96 \mu \mathrm{m}$ & 250.08 & 5.30 & 100.19 & 14.30 & 24.39 & 50.62 & 68.68 & 260.31 \\
\hline $96-75 \mu \mathrm{m}$ & 284.12 & 6.86 & 110.62 & 14.28 & 31.22 & 56.65 & 71.57 & 299.92 \\
\hline$<75 \mu \mathrm{m}$ & 282.04 & 7.27 & 92.58 & 13.74 & 25.55 & 52.94 & 64.64 & 302.15 \\
\hline
\end{tabular}

Shanghai were enriched in particle sizes of $150 \mu \mathrm{m}$ and $75 \mu \mathrm{m}$. Manno et al. [17] reported that most heavy metals in street dust were enrichment in the particle size of 63-125 $\mu \mathrm{m}$. Different metals have different sources, which lead to different distribution rules in different particle sizes.

The concentrations of $\mathrm{Co}, \mathrm{Ni}$, and $\mathrm{Cu}$ for industrial sources in different particle sizes were maximum in the industrial district, and have no obvious difference with other districts. Zn concentration in each particle size dust had obvious difference in the traffic district. $\mathrm{Zn}$ concentration in fine particles was obviously higher than that in coarse particles in the traffic district, and $\mathrm{Zn}$ concentration in the fine particles in traffic district was obviously higher than those in other districts. Zn concentration in different particle sizes had no obvious difference in the residential district and was a little high in coarse particles. Therefore, $\mathrm{Zn}$ in the fine particle dust mainly comes from traffic activities, and $\mathrm{Zn}$ in coarse particle dust mainly comes from soil weathering. High concentrations of $\mathrm{Pb}, \mathrm{Cd}$, and $\mathrm{Cr}$ in the particle size of $<75 \mu \mathrm{m}$ appeared in the industrial district, and high concentrations of $\mathrm{Pb}, \mathrm{Cd}$, and $\mathrm{Cr}$ in other particle sizes appeared in the residential district. The high value of $\mathrm{Cr}$ in the particle size of 150-96 $\mu \mathrm{m}$ and 830-250 $\mu \mathrm{m}$ appeared in the traffic district. The metals from transportation sources may easily be loaded in fine particles. Different heavy metals concentrations in the different particles in different functional districts of Wuhu had different distribution characteristics due to their different sources. Cd concentration in different functional districts had obvious differences, which increased with the decrease of particle size. The concentration of $\mathrm{Cd}$ in the particle size of 96$75 \mu \mathrm{m}$ and $<75 \mu \mathrm{m}$ was significantly higher than those in the other particle sizes, and the difference was especially obvious in the traffic and industrial districts. The max concentration of $\mathrm{Pb}$ in different particle sizes appeared in the residential district, which indicated that $\mathrm{Pb}$ maybe have a complex source, for example car emissions, heating, fuel burning, and other emissions. Cars often drive slowly in residential districts, emitting high amounts of $\mathrm{Pb}$ in the process. In addition to the industrial district, the highest levels of all heavy metals appeared in the particle size 95-75 $\mu \mathrm{m}$. The peak concentrations of heavy metals in the industrial district appeared in the particle size of $<75 \mu \mathrm{m}$. The difference of $\mathrm{Co}$ and $\mathrm{V}$ in each particle size was not significant.

\section{Chemical Speciation of Heavy Metals in Street Dust of Wuhu}

Chemical speciation of heavy metals in street dust in Wuhu city, calculated by the average of 34 samples, are shown in Fig. 2. $\mathrm{Zn}$ and $\mathrm{Cd}$ were given priority to an acid-extractable state, with the average concentrations of $168.07 \mathrm{mg} / \mathrm{kg}$ and $0.71 \mathrm{mg} / \mathrm{kg}$, accounting for $46.72 \%$ and $32.1 \%$ to the total, respectively. Reducible concentrations of the two elements were $40 \%$, and the residual concentration was relatively low. $\mathrm{Zn}$ speciation distribution decreased in the order of acid-extractable $(46.72 \%)>$ reducible $(21.20 \%)>$ oxidizable $(17.32 \%)>$ residual $(14.76 \%)$. The speciation distribution of $\mathrm{Cd}$ decreased in the order of acid-extractable $(32.1 \%)>$ oxidizable $(24.9 \%)>$ residual $(21.7 \%)>$ reducible $(21.3 \%)$. Cd distribution in street dust of Wuhu was relatively uniform in different speciation, which may be explained by the fact that $\mathrm{Cd}$ has different sources. The residual state of $\mathrm{Cd}$ in street dust mainly comes from the earth's crust weathering. The other state may come from coal combustion and tire wear. $\mathrm{Cd}$ in the street dust was given priority to oxidizable state $(43 \%)$. But in Chongqing, $\mathrm{Cd}$ in street dust was given priority to exchange state and carbonate combination state [24]. These results showed that the chemical form distribution of the same element have obvious differences because of various sources.

The elements of $\mathrm{Cr}, \mathrm{V}, \mathrm{Ni}$, and $\mathrm{Co}$ from natural sources were given priority to residual state, and a

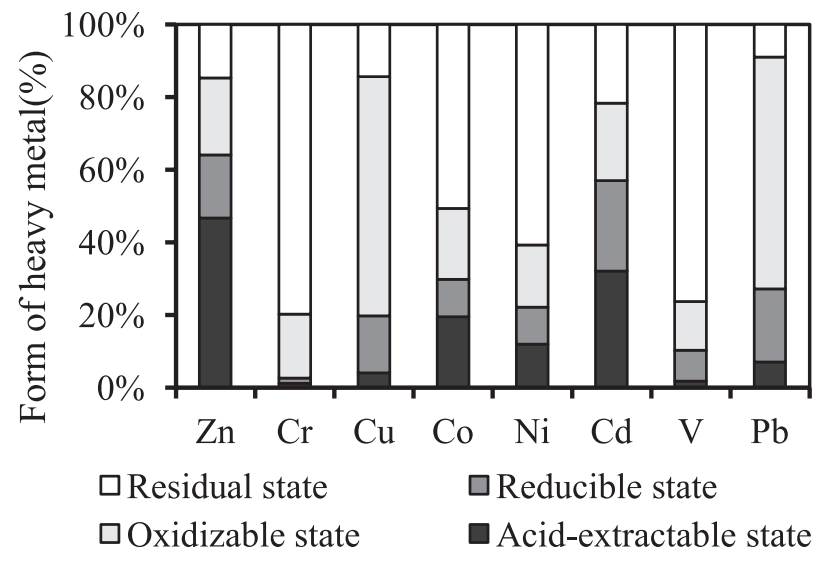

Fig. 2. Heavy metals speciation distribution in urban street dust from Wuhu city. 
verage concentrations were $43.69 \mathrm{mg} / \mathrm{kg}, 44.78 \mathrm{mg} / \mathrm{kg}$, $13.6 \mathrm{mg} / \mathrm{kg}$, and $4.45 \mathrm{mg} / \mathrm{kg}$, respectively. And the ratios to the total were $79.81 \%, 76.3 \%, 60.7 \%$, and $50.7 \%$, respectively (Table 3). The distribution trend of $\mathrm{Cr}$ and $\mathrm{V}$ decreased in the order of residual $>$ oxidizable $>$ reducible $>$ acid-extractable. The distribution trend of $\mathrm{Ni}$ and $\mathrm{Co}$ decreased in the order of residual $>$ oxidizable $>$ acid-extractable $>$ reducible. $\mathrm{Cr}$ was given priority to a residual state belonging to kiss rock elements, easy to form a stable oxygen acid anion, then mainly existing with oxide speciation and usually complexed with silicon dioxide, ferric oxide, and magnesium oxide [25].

$\mathrm{Cu}$ and $\mathrm{Pb}$ were given priority to oxidizable state, and the average levels were $124.42 \mathrm{mg} / \mathrm{kg}$ and $51.68 \mathrm{mg} / \mathrm{kg}$, with the ratios of $65.9 \%$ and $63.8 \%$ of the total, respectively. The reducible ratios of the total were $15.6 \%$ and $20.2 \%$, respectively. The speciation distribution of $\mathrm{Cu}$ and $\mathrm{Pb}$ decreased in the order of oxidizable $>$ reducible $>$ residual $>$ acid-extractable. Oxidizable had strong ability chelating metal ions, and attached to the surface of the mineral grains with the speciation of oxidizable membrane, which changed the surface properties of mineral grains, then can enhance the adsorbtion ability of heavy metals. Meanwhile, $\mathrm{Cu}$ had a strong combination ability with organic matter [26]. The oxidizable state of $\mathrm{Cu}$ and $\mathrm{Pb}$ were influenced by the emissions of oxidizable clastic, coal, oil, and natural gas incomplete combustion and human activity. Iron and manganese oxide and exchange state of $\mathrm{Cu}$ and $\mathrm{Pb}$ were influenced by emissions of mechanical processing, electrical power, and the electrical and electronics industries.

\section{Heavy Metals Bioavailability in Street Dust}

The activity and bioavailability of heavy metals had a relationship with its soluble and chemical speciation. The residual state is a "stable fraction." The high proportion of the residual state leads to less migration and bioavailability, and a little influence on the environment. Acid-extractable, reducible, and oxidizable states were "labile fraction," and when the labile fraction is high, the migration and bioavailability parts of heavy metals are high, which have a great impact on the environment. The bioavailability coefficient $(\mathrm{k})$ can be calculated by the ratio of the sum of acid-extractable, reducible, and oxidizable states to the total heavy metals concentration.

$\mathrm{k}$ in Wuhu street dust decreased in the order of $\mathrm{Pb}$ $(91 \%)>\mathrm{Cu}(85.6 \%)>\mathrm{Zn}(85.24 \%)>\mathrm{Cd}(78.3 \%)>$ $\mathrm{Co}(49.3 \%)>\mathrm{Ni}(39.3)>\mathrm{V}(23.7 \%)>\mathrm{Cr}(20.19 \%)$. According to bioavailability coefficients [26], when $\mathrm{k}<0.2$, heavy metal has stable status. When $0.2<\mathrm{k}<$ 0.8 , heavy metal is relatively stable, but had potential risk, which may pose a threat to human health when the environmental conditions change. When $\mathrm{k}>0.8$, heavy metal is active for biology. By this standard, $\mathrm{Pb}, \mathrm{Cu}$, and $\mathrm{Zn}$ were biologically available elements, and $\mathrm{Cd}$ (78.3\%),

\begin{tabular}{|c|c|c|c|c|c|c|c|c|c|}
\hline \multirow{2}{*}{ 吾 } & $\begin{array}{l}\underset{\infty}{0} \\
\stackrel{\Xi}{\simeq} \\
\end{array}$ & 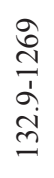 & 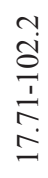 & $\begin{array}{l}a \\
a \\
\sigma \\
-1 \\
\tilde{c} \\
\infty \\
\infty \\
\sim\end{array}$ & 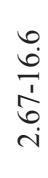 & $\begin{array}{l}\overline{0} \\
\dot{0} \\
+ \\
\vdots \\
0 \\
\vdots \\
= \\
=\end{array}$ & $\begin{array}{l}\infty \\
\stackrel{\infty}{1} \\
\infty \\
0 \\
0\end{array}$ & $\begin{array}{l}+ \\
\stackrel{0}{0} \\
\frac{1}{1} \\
\vec{a}\end{array}$ & 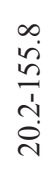 \\
\hline & 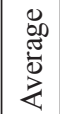 & $\begin{array}{l}\text { o } \\
+ \\
\dot{8} \\
\text { d. }\end{array}$ & $\begin{array}{l}\stackrel{+}{t} \\
\stackrel{\mathbb{N}}{ }\end{array}$ & $\begin{array}{l}0 \\
\infty \\
\infty \\
-1\end{array}$ & $\stackrel{\hat{\infty}}{\infty}$ & $\stackrel{\nabla}{\Delta}$ & $\vec{N}$ & $\stackrel{r}{\infty}$ & 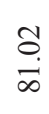 \\
\hline \multirow{3}{*}{ 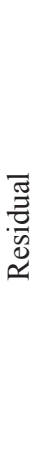 } & $\begin{array}{l}\frac{0}{0} \\
\frac{0}{\tilde{J}} \\
\tilde{n}\end{array}$ & $\begin{array}{l}0 \\
\stackrel{n}{n}\end{array}$ & $\stackrel{\infty}{\stackrel{\infty}{\gamma}}$ & $\stackrel{+}{ \pm}$ & in & $\hat{8}$ & $\hat{\nabla}$ & ?ֶ. & $\stackrel{\circ}{\circ}$ \\
\hline & 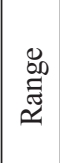 & $\begin{array}{l}\infty \\
\stackrel{\infty}{\circ} \\
\stackrel{n}{1} \\
\stackrel{1}{\infty} \\
\stackrel{\infty}{-1}\end{array}$ & $\begin{array}{l}+\dot{0} \\
\stackrel{0}{o} \\
\dot{1} \\
\stackrel{1}{1}\end{array}$ & 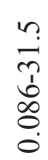 & 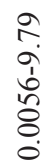 & $\begin{array}{l}n \\
\text { ñ } \\
\text { bे } \\
\text { r. }\end{array}$ & 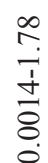 & 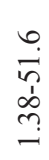 & 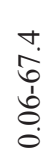 \\
\hline & 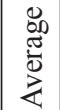 & $\begin{array}{l}\vec{\sim} \\
i n \\
i n\end{array}$ & $\begin{array}{l}\hat{\sigma} \\
\dot{\gamma}\end{array}$ & 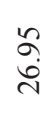 & $\stackrel{?}{\stackrel{f}{f}}$ & $\begin{array}{l}0 \\
\stackrel{0}{2}\end{array}$ & $\stackrel{\infty}{+}$ & $\underset{⿱}{\stackrel{\infty}{+}}$ & $\stackrel{m}{r}$ \\
\hline \multirow{3}{*}{ 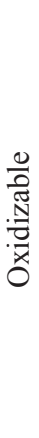 } & $\begin{array}{l}\frac{0}{0} \\
\frac{0}{\tilde{J}} \\
\tilde{n}\end{array}$ & $\stackrel{\vec{\lambda}}{\vec{\lambda}}$ & 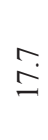 & $\hat{\sigma}$ & $\stackrel{n}{2}$ & $\stackrel{N}{I}$ & $\stackrel{n}{\sim}$ & $\stackrel{+}{\ddot{r}}$ & $\stackrel{\infty}{\pi}$ \\
\hline & 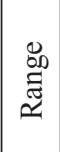 & $\begin{array}{l}\hat{\sigma} \\
\stackrel{1}{1} \\
\text { oे } \\
\dot{d}\end{array}$ & $\begin{array}{l}\infty \\
\infty \\
\dot{\sim} \\
\sim \\
\infty \\
\infty \\
\dot{n}\end{array}$ & 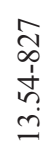 & $\begin{array}{l}n \\
\text { n. } \\
\dot{1} \\
0 \\
n \\
0\end{array}$ & $\begin{array}{l}2 \\
\infty \\
\dot{1} \\
=\end{array}$ & 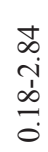 & $\begin{array}{l}\tilde{f} \\
\underset{\sim}{\sim} \\
\hat{\sigma} \\
\hat{\sigma}\end{array}$ & 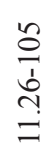 \\
\hline & 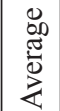 & \begin{tabular}{l}
$\hat{\imath}$ \\
\multirow{2}{*}{}
\end{tabular} & $\begin{array}{l}0 \\
0 \\
0\end{array}$ & $\begin{array}{l}\underset{+}{+} \\
\stackrel{\sim}{J}\end{array}$ & $\vec{F}$ & $\begin{array}{l}\infty \\
\infty \\
\infty\end{array}$ & 守 & $\underset{\infty}{+}$ & $\frac{\infty}{\dot{\infty}} \underset{\dot{n}}{n}$ \\
\hline \multirow{3}{*}{$\begin{array}{l}\frac{0}{0} \\
\frac{0}{0} \\
\frac{0}{0} \\
\simeq \\
\simeq\end{array}$} & 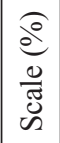 & $\stackrel{n}{I}$ & $\stackrel{+}{\sim}$ & $\begin{array}{l}0 \\
\ddot{n} \\
\end{array}$ & $\stackrel{n}{0}$ & $\stackrel{N}{0}$ & 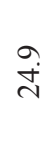 & $\stackrel{n}{\infty}$ & ํ. \\
\hline & $\begin{array}{l}\mathbb{8} \\
\text { त् } \\
\approx\end{array}$ & 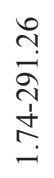 & 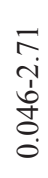 & $\begin{array}{l}r \\
\dot{j} \\
0 \\
0 \\
0 \\
0 \\
0 \\
0 \\
0\end{array}$ & 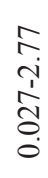 & $\begin{array}{l}\infty \\
\dot{n} \\
\frac{1}{1} \\
\dot{+} \\
\dot{0}\end{array}$ & 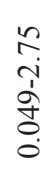 & 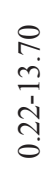 & $\begin{array}{l}8 \\
\dot{0} \\
\dot{0} \\
1 \\
\dot{1} \\
0 \\
0\end{array}$ \\
\hline & 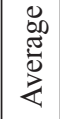 & ָુ & $\stackrel{\circ}{\stackrel{0}{0}}$ & 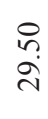 & $\stackrel{8}{\circ}$ & $\begin{array}{l}\infty \\
\sim \\
\sim\end{array}$ & ñ & $\stackrel{\partial}{\partial}$ & $\begin{array}{l}m \\
\text { ?ై } \\
0\end{array}$ \\
\hline \multirow{3}{*}{ 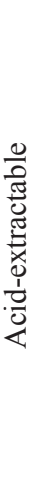 } & $\frac{\widehat{0}}{\frac{0}{0}}$ & $\begin{array}{l}\dot{0} \\
\dot{\sigma}\end{array}$ & $=$ & Ғ & $\ddot{n}$ & $\stackrel{9}{=}$ & $\vec{n}$ & $\stackrel{\infty}{-}$ & $\stackrel{\circ}{\circ}$ \\
\hline & 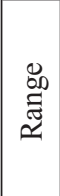 & $\begin{array}{l}0 \\
\infty \\
i n \\
n \\
n \\
n\end{array}$ & 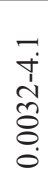 & 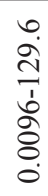 & $\begin{array}{l}0 \\
\dot{J} \\
\frac{1}{1} \\
0 \\
0 \\
0\end{array}$ & $\begin{array}{l}\hat{b} \\
\dot{0} \\
1 \\
\hat{\sigma} \\
\hat{\sigma} \\
0 \\
0\end{array}$ & 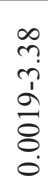 & 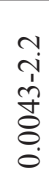 & $\begin{array}{l}\tilde{n} \\
\hat{n} \\
\dot{\delta} \\
0 \\
0\end{array}$ \\
\hline & 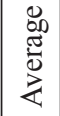 & $\begin{array}{l}\hat{0} \\
\infty \\
0 \\
0\end{array}$ & $\begin{array}{l}\hat{b} \\
0\end{array}$ & $\stackrel{\Re}{\stackrel{2}{r}}$ & 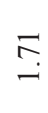 & $\begin{array}{l}0 \\
i \\
i\end{array}$ & $\overrightarrow{0}$ & $\stackrel{0}{0}$ & $\begin{array}{l}\text { P } \\
\text { is }\end{array}$ \\
\hline & 童 & సี & $\dot{U}$ & $\vec{U}$ & $\dot{0}$ & $\bar{z}$ & $\vec{U}$ & $>$ & $\hat{0}$ \\
\hline
\end{tabular}


Table 4. Average concentrations (AC) and $\mathrm{GSF}_{\text {Load }}$ of heavy metals speciation in different particle sizes of street dust (mg/kg; $\left.\mathrm{n}=11\right)$.

\begin{tabular}{|c|c|c|c|c|c|c|}
\hline Element & Speciation & $\begin{array}{l}830-250 \mu \mathrm{m} \\
\mathrm{AC} \mathrm{GSF}_{\text {Load }}\end{array}$ & $\begin{array}{l}250-150 \mu \mathrm{m} \\
\mathrm{AC} \mathrm{GSF}_{\text {Load }}\end{array}$ & $\begin{array}{l}150-96 \mu \mathrm{m} \\
\mathrm{AC} \mathrm{GSF}_{\text {Load }}\end{array}$ & $\begin{array}{c}96-75 \mu \mathrm{m} \\
\mathrm{AC} \mathrm{GSF}_{\text {Load }} \\
\end{array}$ & $\begin{array}{c}<75 \mu \mathrm{m} \\
\mathrm{AC} \mathrm{GSF}_{\text {Load }} \\
\end{array}$ \\
\hline \multirow{4}{*}{$\mathrm{Zn}$} & Acid-extractable & $45.60 / 7.25$ & $49.62 / 12.73$ & $60.55 / 10.16$ & $51.18 / 12.74$ & $86.28 / 57.12$ \\
\hline & Reducible & $29.66 / 6.90$ & $36.28 / 12.32$ & $51.88 / 10.88$ & $61.07 / 18.56$ & $58.42 / 51.34$ \\
\hline & Oxidizable & $49.92 / 13.03$ & $39.23 / 12.37$ & $51.36 / 11.27$ & $64.28 / 21.31$ & $59.18 / 42.02$ \\
\hline & Residual & $42.86 / 8.68$ & $37.90 / 10.95$ & $60.60 / 12.76$ & $66.33 / 15.56$ & $76.82 / 52.05$ \\
\hline \multirow{4}{*}{$\mathrm{Cr}$} & Acid-extractable & $0.41 / 15.31$ & $0.46 / 28.81$ & $0.27 / 10.81$ & $0.18 / 9.07$ & $0.25 / 36.00$ \\
\hline & Reducible & $1.17 / 9.18$ & $1.63 / 28.25$ & $1.08 / 11.63$ & $1.55 / 13.57$ & $1.10 / 37.37$ \\
\hline & Oxidizable & $10.24 / 13.73$ & $8.30 / 14.47$ & $10.49 / 12.20$ & $11.38 / 18.86$ & $9.72 / 40.74$ \\
\hline & Residual & $14.55 / 5.88$ & $22.05 / 11.17$ & $38.62 / 12.74$ & $43.95 / 19.15$ & $42.05 / 51.05$ \\
\hline \multirow{4}{*}{$\mathrm{Cu}$} & Acid-extractable & $5.46 / 13.70$ & $8.39 / 15.11$ & $4.99 / 18.19$ & $6.28 / 11.43$ & $0.80 / 41.57$ \\
\hline & Reducible & $27.15 / 15.34$ & $23.32 / 28.49$ & $0.77 / 10.74$ & $89.04 / 17.94$ & $0.92 / 27.48$ \\
\hline & Oxidizable & $67.48 / 9.57$ & $74.67 / 11.24$ & $136.42 / 12.98$ & $123.26 / 18.98$ & $122.90 / 47.23$ \\
\hline & Residual & $22.78 / 6.91$ & $39.57 / 11.34$ & $121.81 / 9.74$ & $160.13 / 18.60$ & $203.60 / 53.42$ \\
\hline \multirow{4}{*}{ Co } & Acid-extractable & $3.65 / 12.93$ & $1.74 / 18.05$ & $1.39 / 12.27$ & $1.05 / 13.08$ & $0.94 / 43.68$ \\
\hline & Reducible & $1.19 / 7.59$ & $1.00 / 17.23$ & $1.10 / 11.91$ & $1.59 / 17.85$ & $1.19 / 45.41$ \\
\hline & Oxidizable & $1.27 / 9.40$ & $1.24 / 12.70$ & $1.96 / 12.60$ & $2.07 / 19.17$ & $2.00 / 46.12$ \\
\hline & Residual & $4.34 / 6.27$ & $7.22 / 15.38$ & $9.90 / 12.88$ & $10.17 / 18.00$ & $9.98 / 47.48$ \\
\hline \multirow{4}{*}{$\mathrm{Ni}$} & Acid-extractable & $1.46 / 10.86$ & $1.32 / 16.27$ & $1.67 / 13.66$ & $1.40 / 14.57$ & $1.47 / 44.64$ \\
\hline & Reducible & $1.64 / 6.83$ & $2.71 / 19.68$ & $2.29 / 14.89$ & $4.12 / 17.92$ & $2.54 / 40.68$ \\
\hline & Oxidizable & $2.32 / 9.76$ & $3.99 / 18.93$ & $3.15 / 10.82$ & $3.52 / 18.16$ & $3.14 / 42.33$ \\
\hline & Residual & $7.69 / 5.81$ & $11.24 / 13.88$ & $17.01 / 12.09$ & $22.34 / 19.83$ & $18.73 / 48.39$ \\
\hline \multirow{4}{*}{$\mathrm{Cd}$} & Acid-extractable & $0.27 / 9.19$ & $0.31 / 12.16$ & $0.40 / 10.12$ & $0.53 / 16.14$ & $0.56 / 52.39$ \\
\hline & Reducible & $0.29 / 10.40$ & $0.31 / 11.72$ & $0.40 / 10.89$ & $0.55 / 15.49$ & $0.52 / 51.50$ \\
\hline & Oxidizable & $0.53 / 13.24$ & $0.47 / 11.85$ & $0.67 / 11.26$ & $0.79 / 19.22$ & $0.74 / 44.43$ \\
\hline & Residual & $1.51 / 27.15$ & $1.56 / 4.30$ & $3.43 / 6.93$ & $4.55 / 9.75$ & $5.19 / 51.87$ \\
\hline \multirow{4}{*}{ V } & Acid-extractable & $0.32 / 5.98$ & $0.43 / 9.60$ & $1.32 / 17.68$ & $0.53 / 13.10$ & $1.33 / 53.65$ \\
\hline & Reducible & $6.36 / 14.13$ & $6.90 / 23.19$ & $5.85 / 10.24$ & $6.82 / 15.54$ & $4.94 / 36.91$ \\
\hline & Oxidizable & $8.99 / 14.66$ & $7.37 / 16.96$ & $8.13 / 11.27$ & $8.74 / 18.27$ & $7.21 / 38.85$ \\
\hline & Residual & $23.40 / 6.49$ & $37.26 / 14.77$ & $54.27 / 13.23$ & $56.67 / 18.44$ & $52.56 / 47.08$ \\
\hline \multirow{4}{*}{$\mathrm{Pb}$} & Acid-extractable & $1.89 / 10.77$ & $6.44 / 20.87$ & $2.90 / 12.17$ & $1.60 / 10.08$ & $3.20 / 46.10$ \\
\hline & Reducible & $19.35 / 11.25$ & $32.65 / 22.61$ & $6.35 / 4.08$ & $19.87 / 17.05$ & $15.52 / 45.01$ \\
\hline & Oxidizable & $37.32 / 12.69$ & $30.43 / 11.44$ & $59.73 / 13.16$ & $63.00 / 20.91$ & $44.51 / 41.80$ \\
\hline & Residual & $17.68 / 9.68$ & $10.40 / 7.56$ & $32.97 / 13.83$ & $32.37 / 17.72$ & $36.02 / 51.21$ \\
\hline
\end{tabular}

Co $(49.3 \%)$, and $\mathrm{Ni}(39.3 \%)$ were potential biologically available elements.

Wang et al. [22] reported the overall migration order of heavy metals in street dust of Baoji as: $\mathrm{Cd}(90.11 \%)>\mathrm{Pb}$ $(82.33 \%)>\mathrm{Zn}(79.32 \%)>\mathrm{Cu}(62.35 \%)>\mathrm{Co}(29.02 \%)>$ $\mathrm{Ni}(23.62 \%)>\mathrm{Cr}(18.68 \%)$. The bioavailability of heavy metals in street dust of Kayseri decreased in the order of
$\mathrm{Cd}(93.3 \%)>\mathrm{Zn}(83.8 \%)>\mathrm{Pb}(77.2 \%)>\mathrm{Co}(75.9 \%)>$ $\mathrm{Ni}(60.1 \%)>\mathrm{Cu}(59.0 \%)>\mathrm{Cr}(58.6 \%)$ [27]. Therefore, the bioavailability of heavy metals in different urban street dust varied greatly, which is relevant to the differences of regional geochemical background values, industry, energy structure, traffic flow, atmospheric environment, and so on. Although the results of different cities varied, 
generally $\mathrm{Pb}, \mathrm{Cu}, \mathrm{Zn}$, and $\mathrm{Cd}$ are prone to migration, easy to use by living beings. We should pay attention to the high health risks from $\mathrm{Pb}, \mathrm{Cu}, \mathrm{Zn}$, and $\mathrm{Cd}$.

The bioavailability of $\mathrm{Cu}$ in street dust of Wuhu was higher than those of other cities, mainly because of industrial emissions sources. Compared with other cities, the bioavailability of $\mathrm{Cd}$ in Wuhu street dust was low, mainly because of its soil parent material, which is relatively stable. In general, elements emitted from natural sources mainly existed in a residual state. The bioavailability of elements emitted from traffic and industrial sources was relatively high.

\section{Different Speciation of Heavy Metals Loadings in Different Particle Size Fractions}

In order to determine how particles of different grain size contributed to the overall metals loads of the bulk sample, the metals load percentage was computed for each individual sample by combining the concentration data for the grain-size fractions and their mass-size percentages. The grain-size fraction load $\left(\mathrm{GSF}_{\text {Load }}\right)$ was calculated using the following formula [28-29]:

$$
\mathrm{GSF}_{\mathrm{Load}}=\frac{C_{i} \times G S_{i}}{\sum_{i=1}^{m} C_{i} \times G S_{i}}
$$

...where $\mathrm{C}_{i}$ is the heavy metal concentration in an individual grain size fraction in $\mathrm{mg} / \mathrm{kg}, \mathrm{CS}_{i}$ is the mass percentage by mass of the size fraction $i$ in the total sample, and $\mathrm{m}$ is the number of grain-size fractions.

The highest concentrations of acid-extractable, reducible, residual state of $\mathrm{Zn}$ appeared in street dust of the particle size of $<75 \mu \mathrm{m}$, and the $\mathrm{GSF}_{\text {Load }}$ reaches more than $50 \%$ (Table 4). The peak concentrations of oxidizable state appeared in the particle size of 96-75 $\mu \mathrm{m}$, and the $\mathrm{GSF}_{\text {Load }}$ of oxidizable state was $21.31 \%$. The highest concentrations of acid-extractable, oxidizable, reducible, residual state of $\mathrm{Cu}$ appeared in the particle sizes of 250-150 $\mu \mathrm{m}, 150-96 \mu \mathrm{m}, 96-75 \mu \mathrm{m}$, and $<75 \mu \mathrm{m}$, respectively. The source of $\mathrm{Cu}$ in different particle sizes is complex. The distribution differences of reducible state and residual state of $\mathrm{Cu}$ in different particle sizes was obvious. The $\mathrm{GSF}_{\text {Load }}$ of $\mathrm{Cu}$ residual state in fine particle dust was more than $50 \%$. The $\mathrm{GSF}_{\text {Load }}$ of $\mathrm{Cu}$ oxidizable state in the fine particles was $47.23 \%$.

The highest concentration of acid-extractable state Co appeared in particle sizes of $830-250 \mu \mathrm{m}$, and the peak concentrations of other speciation appeared in particle sizes of 95-75 $\mu \mathrm{m}$. Except for the oxidizable state, the $\mathrm{GSF}_{\text {Load }}$ values of other speciations were less than $50 \%$ in particle sizes of $<75 \mu \mathrm{m}$. The highest concentrations of acid-extractable $\mathrm{Ni}$ appeared in the $150-96 \mu \mathrm{m}$ particle size. The difference between particle sizes was not obvious. The peak concentrations of reducible and residual state appeared in particle sizes of 95-75 $\mu \mathrm{m}$. The highest Ni concentrations of oxidizable state appeared in particle sizes of 250-150 $\mu \mathrm{m}$. The $\mathrm{GSF}_{\text {Load }}$ of all speciation was less than $50 \%$ in particle sizes of $<75 \mu \mathrm{m}$

The highest concentrations of acid-extractable state and residual state of $\mathrm{Cd}$ appeared in the $<75 \mu \mathrm{m}$ particle size. The peak concentration of reducible state and oxidizable state appeared in the particle size of 96-75 $\mu \mathrm{m}$. In addition to the oxidizable state, the GSF $\mathrm{Load}_{\text {d }}$ of other speciation was more than $50 \%$ in the particle size of $<75 \mu \mathrm{m}$. The highest concentrations of acidextractable state and reducible state of $\mathrm{Cr}$ appeared in the particle size of $250-150 \mu \mathrm{m}$. The highest concentrations of oxidizable state and residual state appeared in the 250-150 $\mu \mathrm{m}$ particle size. The distribution difference of residual state on the coarse particles and fine particles was big. The highest concentrations of acid-extractable and reducible state of $\mathrm{Pb}$ appeared in the $250-150 \mu \mathrm{m}$ particle size. The residual state mainly was enriched in street dust of particle size $<75 \mu \mathrm{m}$.

Overall, the grain size fraction loads $\left(\mathrm{GSF}_{\text {Load }}\right)$ of different chemical speciation were mainly high in fine particles. The particle size of street dust is more fine, the contributions of heavy metals of different sizes are more vulnerable to the influence of human activity and produce disturbance. Fine particles have larger available surface area and surface energy, and they have a high adsorption rate for metals compared to larger particles [30]. The fine particles concentrate a lot of heavy metals into the atmosphere and cause potential harm to human health.

\section{Conclusion}

The concentrations of $\mathrm{Zn}, \mathrm{Cd}, \mathrm{Pb}$, and $\mathrm{Cu}$ in urban street dust of Wuhu were higher than the background values of Wuhu soil. There existed obvious enrichment and pollution. Concentrations distribution of heavy metals in street dust of different functional districts were obviously different. The $\mathrm{Zn}$ concentration in the traffic district were more than two times that in other districts, $\mathrm{Cu}$ concentration in street dust in the industrial district was more than three times that in other districts. Zn mainly comes from traffic sources, and $\mathrm{Cu}$ mainly comes from industrial emissions sources. Different metals had different sources, leading to different distributions in different particles. Overall, the concentrations of heavy metals were high in the fine particles. The more fine a particle, the more vulnerable it is to the influence of human activity and the more likely to produce a disturbance. Fine particle dust concentrates a lot of heavy metals that can enter the atmosphere and cause potentially harm to human health.

The heavy metal concentrations in different particle dust had different functions in different districts, due to the different sources of coarse and fine particles of each district.

$\mathrm{Zn}$ and $\mathrm{Cd}$ were given priority to acid-extractable state, respectively for $46.6 \%$ and $32.1 \%$ of the total amount, lowresidual state. The elements of $\mathrm{Cr}, \mathrm{V}, \mathrm{Ni}$, and $\mathrm{Co}$, which 
come from natural sources, were given priority to residual state for $50 \%$ above. $\mathrm{Cu}$ and $\mathrm{Pb}$ were given priority to oxidizable states, respectively for $65.9 \%$ and $63.8 \%$ of the total amount. The chemicals from different elements are related to the nature and source of the elements. The grain size fraction loads $\left(\mathrm{GSF}_{\text {Load }}\right)$ of different chemical forms were mainly high in fine particles.

The biological mobility of heavy metals in Wuhu street dust decreased in the order of $\mathrm{Pb}(91 \%)>\mathrm{Cu}(85.6 \%)>\mathrm{Zn}$ $(85.24 \%)>\mathrm{Cd}(78.3 \%)>\mathrm{Co}(49.3 \%)>\mathrm{Ni}(39.3 \%)>\mathrm{V}$ $(23.7 \%)>\mathrm{Cr}(20.19 \%) . \mathrm{Pb}, \mathrm{Cu}$, and $\mathrm{Zn}$ were biologically available elements, and the biological mobility of $\mathrm{Cu}$ was much higher than those in other reports due to $\mathrm{Cu}$ emitted from the industry source in Wuhu. A partition difference of combined speciation of different elements was different. The different form distribution of $\mathrm{V}, \mathrm{Zn}$, and $\mathrm{Cr}$ in different functional districts had no obvious difference. The proportions of an ecologically effective state of most elements in industrial and residential districts were big. In the residential district the metals can harm human health, which should be a cause for serious concern.

\section{Acknowledgements}

Our research was supported by the National Natural Science Foundation of China through grant No. 41371480 and the Anhui Key Laboratory of Natural Disaster Process and Protection Research.

\section{References}

1. AWADH S.M. Cd, Ni, and $\mathrm{Pb}$ distribution and pollution assessment in roadside dust from Baghdad City and Western Iraqi Desert. Arab. J. Geosci. 8, 315, 2015.

2. CHARLESWORTH S., EVERETT M., MCCARTHY R., ORDEZ A., DE-MIGUEL E. A comparative study of heavy metal concentration and distribution in deposited street dusts in a large and a small urban area: Birmingham and Coventry, West Midlands, UK. Environ. Int. 29, 563, 2003.

3. ALGHAMDI M.A. Characteristics and risk assessment of heavy metals in airborne PM10 from a residential area of Northern Jeddah City, Saudi Arabia. Pol. J. Environ. Stud. 25, 939, 2016.

4. ZHENG N., LIU J.S., WANG Q.C., LIANG Z.Z. Heavy metals exposure of children from stairway and sidewalk dust in the smelting district, northeast of China. Atmos. Environ. 44, 3239, 2010.

5. HAN X.F., LU X.W., ZHANG Q.H., WU Y.T., HAI Q.S., PAN H.Y. Grain-size distribution and contamination characteristics of heavy metal in street dust of Baotou, China. Environ. Earth Sci. 75, 468, 2016.

6. CHEN M.Q., PI L., LUO Y., GENG M., HU W.L., LI Z., SU S.J., GAN Z.W., DING S.L. Grain size distribution and health risk assessment of metals in outdoor dust in chengdu, southwestern china. Arch. Environ. Contam. Toxicol. 70, 534, 2016.

7. WANG W.H., WONG M.H., LEHARNE S., FISHER B. Fractionation and biotoxicity of heavy metals in urban dusts collected from Hong Kong and London. Environ. Geochem. Hlth. 20, 185, 1998.
8. ROUT K., MASTO E.R., PADHY P.K., RAM L.C., GEORGE J., JOSHI G. Heavy metals in dusts from commercial and residential areas of Jharia coal mining town. Environ. Earth Sci. 73, 347, 2015.

9. YANG Z.P., GE H.K., LU W.X., LONG Y.Q. Assessment of heavy metals contamination in near-surface dust. Pol. J. Environ. Stud. 24, 1817, 2015.

10. SHEN Z.Y., LIU J., AINI G.H., GONG Y.W. A comparative study of the grain-size distribution of surface dust and storm water runoff quality on typical urban roads and roofs in Beijing, China. Environ. Sci. Pollut. Res. 23, 2693, 2016.

11. WANG L.T., ZHAO J.W., DUAN B.Z., ZHU D.W., HUA Y.M., ZHOU W.B., LIU G.L. Characteristics of street dust in Jiansheng town, Chongqing City, China. Environ. Prog. Sustain. 35 (3), 794, 2016.

12. DELETIC A.B., ORR D.W. Pollution buildup on road surfaces. J. Environ. Eng. 131 (1), 49, 2005.

13. LIU Q., WANG Y., LIU J., WANG Q., ZOU M. Grain-size distribution and heavy metal contamination of road dusts in urban parks and squares in Changchun, China. Environ. Geochem. Hlth. 37, 71, 2015.

14. BI X., LIANG S., LI X. A novel in situ method for sampling urban soil dust: Particle size distribution, trace metal concentrations, and stable lead isotopes. Environ. Pollut. 177, 48, 2013.

15. MCKENZIE E.R., WONG C.M., GREEN P.G., KAYHANIAN M., YOUNG T.M. Size dependent elemental composition of road-associated particles. Sci. Total Environ. 398, 145, 2008.

16. FERREIRA-BAPTISTA L., DE-MIGUEL E. Geochemistry and risk assessment of street dust in Luanda, Angola: A tropical urban environment. Atmos. Environ. 39, 4501, 2005.

17. MANNO E., VARRICA D., DONGARRA G. Metal distribution in road dust samples collected in an urban area close to a petrochemical plant at Gela, Sicily. Atmos. Environ. 40, 5929, 2006.

18. CHANG J., LIU M., LI X.H., LIN X., WANG L.L., GAO L. Fractionation and bioavailability of heavy metal contamination of urban surface dusts in Shanghai city. Environ. Sci. 29 (12), 3489, 2008 [In Chinese].

19. FANG F.M., JIANG B.Y., WANG H.D., XIE H.F. Particle size distribution and health risk assessment of heavy metals in surface dust of Wuhu urban area. Geogr. Res. 29 (7), 1193, 2010 [In Chinese].

20. UMOREN I.U., UDOHA.P., UDOUSORO I.I. Concentration and chemical speciation for the determination of $\mathrm{Cu}, \mathrm{Zn}, \mathrm{Ni}$, $\mathrm{Pb}$ and $\mathrm{Cd}$ from refuse dump soil using the optimized BCR sequential extraction procedure. Environmentalist. 27 (2), 241, 2007.

21. HAN L.H., ZHUANG G.S., CHENG S.Y., WANG Y., LI J. Characteristics of re-suspended road dust and its impact on the atmospheric environment in Beijing. Atmos. Environ. 41, 7485, 2007.

22. WANG L.J., LU X.W., LEI K., ZHAI Y.X., HUANG J. Content, source and speciation of heavy metal elements of street dusts in Baoji City. Environ. Sci. 32 (8), 2470, 2011 [In Chinese].

23. WANG H.D., FANG F.M., XIE H.F., WANG X., HUANG C.H. Pollution evaluation and source analysis of heavy metal in urban soil of Wuhu city. Urban Environ. Urban Eco. 23 (4), 36, 2010 [In Chinese].

24. LI Z.P., CHEN Y.C., YANG X.C., WEI S.Q. Heavy metals contamination of street dusts in core zone of Chongqing municipality. J. Soil Water Conserv. 20 (1), 114, 2006.

25. TIAN H. Occurrence state of the trace elements of the dust in the street of Xian. Beijing Geo. 14 (2), 34, 2002 [In Chinese]. 
26. IMPERATO M., ADAMO P., NAIMO D., ARIENZOB M., STANZIONEA D., VIOLANTEB P. Spatial distribution of heavy metals in urban soils of Naples city (Italy). Environ. Pollut. 123, 247, 2003.

27. TOKALIOGLU S., KARTAL S. Multivariate analysis of the data and speciation of heavy metals in street dust samples from the organized industrial district in Kayseri (Turkey). Atmos. Environ. 40 (16), 2797, 2006.

28. SUTHERLAND R. A. Lead in grain size fractions of road deposited sediment. Environ. Pollut. 121 (2), 229, 2003.
29. ZHAO H., LI X., WANG X. Heavy metal contents of roaddeposited sediment along the urban-rural gradient around Beijing and its potential contribution to runoff pollution. Environ. Sci. Tech. 45, 7120, 2011.

30. DUONG T.T.T., LEE B.K. Partitioning and mobility behavior of metals in road dusts from national-scale industrial areas in Korea. Atmos. Environ. 43 (22-23), 3502, 2009. 
